\title{
NATURAL RESOURCE AND WATERSHED MANAGEMENT IN SOUTH ASIA: A COMPARATIVE EVALUATION WTH SPECIAL REFERENCES TO NEPAL
}

\author{
Krishna R. Tiwari (PhD student) ${ }^{15}$ Roshan M. Bajracharya $(\mathrm{PhD})^{16}$ and Bishal K. Sitaula $(\mathrm{PhD})^{17}$
}

\begin{abstract}
The paper discusses different approaches of watershed management programs implemented in South Asian countries, with special reference to Nepal based on existing literature and field experiences. Watershed degradation, particularly in mountainous areas, is critical problem in South Asian countries. A participatory approach has been adopted in watershed and natural resource management during the last decade in many developing countries. The participatory community-based watershed management approach in Nepal is viewed from two perspectives. The first, success of conservation of natural resources with formation and strengthening of the local level institutions in rural areas of the country; the second, its multiplier effects in social mobilization, women empowerment, community development and livelihood improvement as well as good governance at local level. In the present context, participatory watershed management must include not only environmental protection but also supporting poor and disadvantaged segments of society in improving their livelihoods.
\end{abstract}

Key words: Bottom-up approach, empowerment, participatory approach, resource management, top-down approach and watershed degradation

\section{INTRODUCTION}

The importance of watersheds as ecological units in the context of natural resource management and conservation cannot be overstated. They are hydrologic units that are often used as biophysical and socio-economic or political units for the planning and management of natural resources (Brooks et al., 1991). A watershed is a topographically delineated area that is drained by a stream system i.e. all of the land draining its rain, snowmelt and ground water into a stream or river (Corn, 1993; Swallow et al., 2001).

Watershed management can be regarded as both a science and an art (Swallow et al., 2001). Broadly, it is "the process of guiding and organizing land and other resources use in a watershed to provide desired goods and services without adversely affecting land resources. It integrates various aspects of hydrology, ecology, soils, physical climatology and other sciences to provide guidelines for choosing acceptable management alternatives within the socio-economic context taking into consideration the interactions and implications among land resources and the linkages between uplands and downstream areas" (Brooks et al., 1991; Sen et al., 1997). Historically, the conceptual development of integrated watershed management has been attributed to small mountainous drainage areas where forestry schools or universities and their field practices have been the main driving force (Ozyuvaci et al., 1997). In the early days watershed management had a narrow focus primarily for controlling erosion, floods and maintaining sustainability of useable water yield (Ozyuvaci et al., 1997).

\footnotetext{
15 PhD student, Department of Plant and Environmental Sciences, Norwegian University of Life Sciences

${ }^{16}$ Associate Professor, Department of Biological and Environmental Science, KU, Nepal

${ }^{17}$ Prof. in Dept of International Env. and Dev. Studies (Noragric), Norwegian University of Life Sciences
} 
However, in the present context, watershed management is not only for managing or conserving natural resources in a holistic manner, but also to involve local people for betterment of their lives (Mountain, 2002). Thus, modern watershed management is more people oriented and process based, unlike many of the programs in the past, which were physically target oriented. It is meant to fit into the farmers' lifestyles rather than merely fulfilling the purposes of donors, governments, or non-government agencies (Sen et al., 1997).

Table1. Different Aspects of Watershed Management in Developing and Developed Countries

\begin{tabular}{l|l|l}
\hline Activities & Developing countries & Developed countries \\
\hline Output & Farm production & Water yield \\
Focus & Livelihoods of the communities & Water quality \\
Program & Community based socio-economic activities & More on natural resource management \\
Approach & Applied science and participatory approach & Science based \\
Action & People oriented & Natural resource oriented \\
\hline
\end{tabular}

Nonetheless, the objectives of watershed management in developing and advanced countries have distinct differences as shown in Table 1. In case of developing countries, watershed management is more focused on local people's requirements and sustainable livelihoods, whereas in advanced countries, it is focused on water quality and supply. This paper concentrates more on different watershed management approaches applied in developing countries of South Asia, with particular reference to Nepal and analyses their strengths and weaknesses. The motivations behind this review paper are three fold. Firstly, watershed degradation is a major problem in mountainous regions of South Asia. Secondly, watershed management is directly linked with environment and livelihoods of the rural areas. Finally, different approaches to watershed management impact upon sustainable conservation of the natural resources and livelihoods of the local communities.

\section{Overview of land degradation in developing countries}

During the last few decades, degraded watersheds have posed serious problems to environment and people, both upstream and downstream (Mountain, 2002). The people of developing countries came to the realization that land degradation was a serious threat to the environment and to the well being of millions of people (Ives and Messerli, 1989; Oldeman, 1994; J odha, 1995; Lal, 1998). As it is often the result of human activities, it can therefore, be prevented or controlled by human efforts. Degradation of land resources is a global phenomenon and worldwide soil degradation affects over 2 billion ha of land, putting at risk the livelihoods of more than 1 billion people (ESC, 2001). Perera and Fernado (2004) reported that 43 percent of the agricultural lands in 8 South Asian countries were affected by some form of degradation. It was also estimated in the GLASOD study that 25 percent of the regions' cultivated land had been degraded by water erosion, 18 percent by wind erosion, 13 percent by soil fertility decline, 2 percent by water logging, 9 percent by salinization and 6 percent by lowering of the water table (Young, 1994). Erosion by water is the most serious degradation problem in South Asia (Narwal et al., 2003). Past studies have indicated that water erosion is detrimental to soils globally both by the volume of soil removed and area of land influenced. It is reported that 1094 million ha is degraded globally due to water erosion of which 751 million ha is severely affected (Lal, 2002) while in Asia, 15 percent of the total land is seriously eroded (Scheer, 1999). Partap and Watson (1994) reported that about 42 million ha of land has been degraded in mountain regions of South Asia. Past reports indicated that the status of much of the natural resources in the mountains of South Asia has been deteriorating. A steady flow of information regarding the unhealthy state of the world 
environment became available from the 1970s prompting actions first in the advanced countries, followed by greater international awareness and subsequently local level action in the developing nations (Ives and Messerli, 1989; Carson, 1992; Meadows, 2003; Sitaula et al., 2004). The 'Theory of Himalayan Environmental Degradation' (THED) (Eckholm, 1975) referring that the degradation of forest resources, improper land use and cultivation of crops on fragile steep land due to population pressure are the main causes of accelerated soil erosion and land degradation across the Himalayan region impacting the plains. It implies that a few million Himalayan hill farmers are responsible for the massive landscape changes that affect the lives and property of several hundred millions people living in Gangatic plain in India and Bangladesh (World Resource Institute, 1985; Rasul and Karki, 2007). The fundamental perception of the 'Theory of Himalayan Environmental Degradation' (Ives, 2004) has been changed over time as many researches conducted in mountain areas after the 1990s have found that only anthropogenic factors are not responsible for Himalayan degradation (Blaikie, 2001). Furthermore, farmers adopted different soil conservation technologies as well as government's policy and programs such as community forest management, watershed management, and protected area management have been addressed to minimize forest and land degradation. The theory ignores the natural factors such as active geology, steepness, fragility, high rainfall and local evolved land management factors that also contribute to environmental degradation in the mountain areas of the Indian sub-continent. In recent decades, as a result of the increasing population growth at a rate of 2.17 per annum (Global Health Facts, 2006) and development of infrastructure in mountain areas (midhill), subsistence agriculture has been intensified into commercial vegetable farming to meet the increased demand of food and day to day household expenditures (Paudel and Thapa, 2004; Brown and Kennedy, 2005). This agricultural intensification with use of high yielding modern varieties and agrochemicals has many negative implications particularly for the unique landscape of the mountains where farmers are dependent on the local resources through locally developed technology (Sen et al., 2002). The degradation will have direct negative impacts on lives of 150 million people living in the $\mathrm{HKH}$ region and indirectly affect about 450 million more living downstream (Rasul and Karki, 2007), and has raised serious concerns about sustainability of mountain farming.

\section{APPROACHES TO WATERSHED MANAGEMENT IN DEVELOPING COUNTRIES OF SOUTH ASIA}

A few notable approaches have been employed in watershed and resource management in southern Asia over the past half-century or so. These evolved in a more or less sequential manner as listed below:

\section{Sectoral vs. integrated approach}

Sectoral approach can be understood as activities targeted for particular sectors such as natural resource management. During the early period (70s-80s) in developing countries, both non-government and government agencies had sectoral narrow approach. The objective was to implement watershed management projects with the aim of land improvement, soil and water conservation, and forest management in mountain areas (Pretty and Shah, 2000). They were focused more on soil conservation activities applying technical measures such as terracing, contour-bunding, landslide and gully control and plantation on degraded land (Rhoades, 1998; Pretty and Shah, 2000; Johnson et al., 2001). The emphasis was on building physical structures to control soil erosion and to rehabilitate degraded lands, and massive efforts were undertaken in this regard (Dejene, 2003). The Mahaveli scheme in Srilanka, and 
the Tarbela dam in Pakistan are examples of the largest sectoral approach irrigation projects in the world during the 1970s (ESCAP, 1997).

Although the concept of watershed management should, by default, be integrated and interdisciplinary (Montgomery et al., 1995; UNEP, 2004), many of the developing countries followed a sectoral approach implemented by different governmental agencies. They generally followed their national level targets based on their policy and plans. Paudel (2002) reported that sectoral integration often takes place at higher levels where decisions are made on allocation of resources. At the implementation level there is little integration among the line agencies. At the field level most line agencies implemented their programs separately according to their own targets and priorities (Paudel, 2002). For example in India, departments are highly sectoral. Staffs have a strong allegiance to their particular professional cadre and are not accustomed to working collaborately (Kumar and Bakshi, 2002). The holistic nature of an ecosystem requires holistic management since one sector's activity will affect another's responsibilities. Sectoral approach is unsuitable for the environment, especially at the field level resource management. Conflicts between government agencies with different priorities (e.g. regarding the use of national parks and mangrove forests) will arise (ESCAP, 1997). In such cases there is problem of duplication, coordination and integration of the program. Even within a single ministry, different departments exhibit lack of integration and coordination. The sectoral approach is no longer appropriate (Shah and Schreier, 1995) in watershed management programs, because each sector constitute independent entities within the administrative and bureaucratic system whereas watershed components such as land, water, vegetation, livestock and human activities are all interlinked each other. Townsely (1996) pointed out that sectoral division are meaningless at the local level particularly the poor watershed communities. Thus, the classic definition of watershed management has been modified by introducing the concept of integration and better sustainability of land, water and socio-economic resources to enhance environment quality and human welfare (Ozyuvaci et al., 1997). Most natural environments in developing countries are not so easily conceived or modelled, and people are not closely integrated with their environments (Swallow et al., 2001).

Integrated Watershed Management (IWM) which emerged in the 1980s can be defined as a comprehensive multi-resource management planning process, involving all stakeholders within the watershed, who together as a group, cooperatively work toward identifying the watershed's resource issues and concerns, as well as developing and implementing a watershed plan with solutions that are environmentally, socially and economically sustainable (Botero, 1986; UNEP, 2004). The holistic approach allows organizations and stakeholders to consider "a system in the context of the higher levels in which it is embedded, and provide insight into the significance of phenomena at lower levels" (Thurow and J uo, 1995; Archer and Smeins, 1991).

IWM has come to be recognized internationally as an important holistic approach to natural resources management, which seeks to promote the concept of sustainable development (FAO, 1998). Such an integrated approach has been recommended in Agenda 21 of the Earth Summit of 1992 for all sectors dealing with the development and management of water resources (UNCED, 1992). It not only deals with the management of natural resources but also involves community development and economic activities (UNCED, 1992; JICA/ HMG(N), 1998). Promoting integrated watershed development programs through the effective participation of local people is intended to prevent further ecological imbalance. Such an approach is needed for conserving, upgrading and using land, water, plant, animal and human resources 
(Mountain, 2002). Experience has shown that a sectoral approach to natural resource development must be replaced by an integrated management approach with multiple stakeholders' participation to address the environment issues and livelihoods of the rural communities.

Top-down approach vs. bottom-up approach

Top-down approach assumes comprehensive scope and strictly follows a formal process (Leganza and Brown, 2004) to give priority to the biophysical framework of watershed in the early periods of watershed management programs (Douglass and Lawrence, 1997). Although called integrated management, the government fixed the targeted plan and implemented it directly by contractor or their own staff without consulting the local people (Ohler et al., 2000). This approach encountered many difficulties in terms of cost, maintenance, management, and implementation.

Since its inception during the early 1970s, the approach to resource management in Nepal consisted of top-down planning, implementing and monitoring of activities. Available maps and aerial photos were used to assess land and forest resources. Targets were fixed based on available budgets. Terrace improvement programs were administrated as individual farm activities, and other activities were planned for public land based on project quotas (Ohler et al., 2000). These types of activities, mainly focused on engineering work, were expensive for construction and maintenance (DSCWM, 2004). Target oriented top-down approach was not very successful for watershed management, but it has some strengths. Experience has shown that centralized 'top-down' conservation is only effective with large expenditures allocated for enforcement or under autocratic governance (CIESIN, 2004).

Farrington and Lobo (1997) discussed that in the Indian context, where a great deal of emphasis has been placed on watershed development, 99 percent of projects are still based on conventional approaches emphasising physical planning without attention to local economic, social or ecological conditions. Many watershed management projects throughout the world have failed because they have been top-down, fixed or rigid technology solutions geared to replace, instead of complement local conservation practices (Peraz and Tschinkel, 2003; Hudson, 1991). Despite an overabundance of participatory assessments, the provision of extension services by many implementing organizations is strictly practiced on a top-down basis (Thurow and Juo, 1995; Peraz and Tschinkel, 2003).

By imposing new soil conservation technologies, there was a tendency to replace rather than supplement local methods of soil and watershed management in places where these had been practiced (Maarleveld, 1998). Often the result of these centrally controlled soil and water conservation programs has been more erosion than previous (Kerr et al., 1996; J ohnson et al., 2001). Furthermore, watershed planning was done based on biophysical capability consideration rather than capacity and need of the local people (Datta and Virgo, 1998). Such planning generally did not accommodate the interests of all stakeholders, nor learned from their feedback (Peraz and Tschinkel, 2003).

Numerous studies elucidate the negative feelings of local people towards an alien effort of management, which the community has failed to understand and accept. Examples of such sentiment include acts like arson fires and illegal grazing in forest plantations, lack of maintenance in conservation work and theft of stakes, barbed wire and other materials, intended for protection of resources (Botero, 1986; Saxena et al., 2003). The conventional 
top-down approach was ineffective due to neglect of the local knowledge, traditional practices, socio-economic conditions and available resources (Hurni and Tato, 1992; Pretty and Shah, 2000). It is widely acknowledged that many of the soil conservation policies and activities in the past decades have not been successful (Pender and Ehui, 2000; Johnson et al., 2001).

The bottom-up approach involving decentralization of planning and policy formulation has become popular in developing countries over the last decade. It is built-up on the principle of devolution of power and authority to local communities for management, utilization and conservation of the resources (Balogun, 2000; Wagley and Ojha, 2002; World Resource Institute, 2003). It includes the democratic process of participation of the local people for planning, implementing and decision making for community development at the local level. Although decentralization efforts in developing countries go back to the early 1960s, most efforts to introduce democratic components emerged in the later 1980s (Blair, 2000). Bottomup approach is practical for managing natural resources provided authority and empowerment is not confined to the local life as frequently tends to be the case. Farrington and Baumann (2003) as well as J honson (2001) exposed the dangers of decentralization, which often simply empowered the local elites and perpetuated existing poverty and inequality.

Nonetheless devolution of authority for natural resource management is shifting the responsibility for forest land and watershed management from government bureaucracies to local level community groups in many part of the developing world (Wagley and Ojha, 2002) and this shift can lead to significant gains in the efficiency of resource use and management (Swallow et al., 2001). The initiation of the decentralization policy in Nepal was with adoption of the buttom-up approach in the early 1980s (Wagley and Bogati, 1999).

Decentralization Act of 1982 authorized users' groups to manage land, forest and water resources in Nepal. Local village leaders or key persons were included in the planning phase, and the inputs of Village Development Committee (VDC), District Development Committee (DDC), as well as government departments were taken into consideration in the planning and decision making process (Wagley and Ojha, 2002). User groups (UG) were established in view of maintenance and repair the project support activities (J ICA/HMG(N), 1998; Ohler et al., 2000). Drawback of the bottom-up approach, however, includes delay in release of funds from the central government and still target oriented, government focused and decision making employed by local leader.

\section{PARTICIPATORY APPROACH}

\section{Participatory watershed management (pwm)}

Over the past decade the word 'participatory' has been incorporated into the vocabulary of government (GA) and non-government organizations (NGO) projects and programs both at the level of implementation and research (Rhoades, 1998). Participatory is now a basic principle in any development activities and natural resource management programs in most developing countries. It is generally believed to be a good thing in development theory and key feature of natural resource management (NRM) (Walker and Carpenter, 2002). The ideology of development through participation has been particularly influential in the field of NRM (Adams, 2001). There has been a rapid expansion of participatory approaches, which involves interactive learning between professionals and farmers (Maarleveld, 1998; Sikka and Samra, 
2000). Watershed management has evolved into a participatory multi-stakeholder exercise requiring institutional and organizational coordination to take into account the economic, social, political and cultural dimensions (Peraz and Tschinkel, 2003).

The definition of participation largely depends upon the context and background in which it is applied. Cohen and Uphoff (1977) point out that participation should include people's involvement in decision-making, implementation of programs, sharing in the benefits of development, as well as involvement in efforts to evaluate such programs. FAO (1982) elaborated that peoples' participation is essential to enhance economic and political relationship within the wider society. It is not just a matter of involvement in project activities but rather the process by which rural people are able to organise themselves and, through their own organisation, to identify their own needs and share in design, implementation and evaluation actions. Kumar (2002) as well as Pretty (1995) classified different levels of participation ranging from passive participation to self-mobilisation.

The participatory approach has come increasingly into favour in development thinking in recent years (Gill, 1995), and South Asia has played a leading role in popularising its adoption in both government and NGOs. The rationale for popularising and funding participatory approaches is to redress the signs of the top-down, heavily subsided approaches of the past, which alienated local populations and often contributed to further land and water degradation (Rhoades, 1998). Thus, participatory approach is full involvement of local people in the identification of priority problems and potential solutions with a team of scientists, planners and development specialists (Blackburn and Holland, 1998). It is bottom-up from participation in the sense that the local people engage in planning, implementing, evaluating and control over the process.

The approach to people's participation in watershed management in Nepal, has been evolving since 1974 (Sharma and Wagley, 1996). Its evolution can be divided into four stages. In each stage people's participation has been described in terms of a five-part project cycle: watershed resources assessment; project activity planning; implementation, maintenance, follow-up and benefit sharing; and extension efforts. But in the absence of legal framework for people's participation in the past, influential persons attempted to obtain all the benefits of a project's activities in the name of community participation (Sharma and Wagley, 1996). People's participation in watershed management has gradually increased after the Decentralization Act in 1982 and it has been institutionalised since 1991.

Participatory NRM was introduced as a consequence of the failure of the past approaches. The wide failure of past policies and control mechanisms to effectively manage natural resources and rise of more democratic regimes have led to new opportunities for negotiation between the government and local people. In the past, enforcement often was unsuccessful because of increasing population and more demands on the natural resource base. The approach of integrating conservation and livelihoods improvement attempts to link enforcement with compensation to the communities that are directly affected by the presence of natural area (Conroy et al., 2002). Realization of the continuous degradation of the natural resources and conflict between rural communities as well as high cost and difficulty in enforcement through traditional state control approach led policy to the aforementioned changes over the last decade or so. Policy makers realized that it was difficult to manage natural resource without local peoples' participation (Makela, 1999). 
To succeed, watershed management has to be participatory (Johnson et al., 2001). At present, PWM is the foremost program in most developing countries for natural resource management, land improvement and livelihoods enhancement of the people. In Bangladesh natural resource management policy addresses active community participation in planning, development and management activities (ESCAP, 1997). In China, series of land related laws pertaining to agricultural and natural resource management issues were enacted to unify the land management process. Public participation is also a fundamental requirement in China's approach to watershed management (ESCAP, 1997).

Table 2. Comparing the Past Traditional and Current Development Approaches

\begin{tabular}{|c|c|c|}
\hline $\begin{array}{l}\text { Development } \\
\text { elements }\end{array}$ & Traditional approach & Current approach \\
\hline Purpose & Single (Soil conservation) & Multiple (Social, economical and environmental) \\
\hline $\begin{array}{l}\text { Need } \\
\text { assessment and } \\
\text { planning }\end{array}$ & $\begin{array}{l}\text { Central level government } \\
\text { staff }\end{array}$ & $\begin{array}{l}\text { Community help to identify the gap and select the } \\
\text { priorities }\end{array}$ \\
\hline Strategy & $\begin{array}{l}\text { Increase production and } \\
\text { conservation }\end{array}$ & $\begin{array}{l}\text { Emphasis on livelihoods, poverty and } \\
\text { sustainability }\end{array}$ \\
\hline Approach & $\begin{array}{l}\text { Centralise, Top-down } \\
\text { planning with little input } \\
\text { from community }\end{array}$ & $\begin{array}{l}\text { Participatory, community based focus to the } \\
\text { women and poor communities }\end{array}$ \\
\hline Institution & $\begin{array}{l}\text { Government and donor } \\
\text { agencies }\end{array}$ & $\begin{array}{l}\text { NGO, community based organization }(\mathrm{CBO}) \text { and } \\
\text { private and Governments institutions }\end{array}$ \\
\hline Working & Large watershed & Small watershed, sub watershed \\
\hline Output & Target meet, quantities & Qualitative, sustainability \\
\hline
\end{tabular}

The Government of India initiated participatory process in watershed management by establishing integrated wastelands development program in 1992 (Sikka and Samra, 2000). To prevent land degradation and manage natural resources in micro watershed, the approach has been practiced in India (Turton, 2000). These micro-watershed projects are undertaken in close consultation with the watershed communities, based on local farming experiences and directed towards the solution of the basic problems faced by local farmers (Farrington and Baumann, 2003). Some successful examples of the participatory natural resource management and rural development programs in South Asia include: Community Forestry in Nepal, Gal Oya Irrigation Project in Srilanka, Participatory Watershed Movement in Rajasthan, India and Aga Khan Rural Support Program in Pakistan (Pokharel, 2000; ESCAP, 2003). Nepal is one of the leading countries in the areas of community based natural resource management (CBNRM) in the South Asia region (Pokharel, 2000). It is recognized as a World leader in community forestry and has experienced community forest management over the past 25 years. At present people's participation is the basic requirement in the watershed management program (Wagley and Bogati, 1999). An overall comparison of the different watershed management approaches is provided in Table 2.

\section{EVOLUTION OF WATERSHED MANAGEMENT PROGRAMIN NEPAL}

In 1974, His Majesty's Government of Nepal established Department of Soil and Water Conservation (DSCWM) under the Ministry of Forest to improve mountain watersheds. The department has been planning, implementing and monitoring soil conservation activities within a framework of the principles of integrated watershed management (IWM) since last two decades (Wagley and Bogati, 1999). IWM approach was designed from the very beginning in the watershed management program. It clearly marks major step forward in terms of 
addressing the problems of watershed communities in all their complexities (Paudel, 2002). However in early periods (70s-80s), only central level (top-down) target oriented, physical engineering conservation method was practiced in watershed management program (J ICA/ HMG(N), 1998; Ohler et al. 2000). The watershed management approaches gradually included the bottom-up planning and people's participation. Different stages in the evolution of watershed management in Nepal are described in the Table 3.

Table 3. Watershed Management Approaches Adopted by Department of Soil Conservation and Watershed Management

\begin{tabular}{|c|c|c|}
\hline Year & Approaches & Activities \\
\hline $\begin{array}{l}\text { First Stage } 1974 \\
\text { to } 1980\end{array}$ & $\begin{array}{l}\begin{array}{l}\text { Central level planning } \\
\text { (top-down) }\end{array} \\
\end{array}$ & $\begin{array}{l}\text { Project based activities conducted by construction } \\
\text { companies or hired labour. }\end{array}$ \\
\hline $\begin{array}{l}\text { Second Stage } \\
1981 \text { to } 1985\end{array}$ & $\begin{array}{l}\text { Initiation of } \\
\text { Decentralization }\end{array}$ & $\begin{array}{l}\text { Key persons or local leaders were taken into consideration } \\
\text { in the project implementation process. }\end{array}$ \\
\hline $\begin{array}{l}\text { Third Stage } \\
1986 \text { to1990 }\end{array}$ & $\begin{array}{l}\text { In line with } \\
\text { decentralization }\end{array}$ & $\begin{array}{l}\text { VDC, DDC and DSCO on project implementation were } \\
\text { taken into consideration in planning process, user groups } \\
\text { were established. Started to handover community } \\
\text { forestry. }\end{array}$ \\
\hline $\begin{array}{l}\text { Fourth stage } \\
\text { (1991 to 1994) }\end{array}$ & $\begin{array}{l}\text { Bottom-up approach, and } \\
\text { people's participation }\end{array}$ & $\begin{array}{l}\text { Sub-watershed planning was institutionalised. Most } \\
\text { activities were implemented through users. RRA, PRA } \\
\text { techniques came into use to collect socio-economic data. }\end{array}$ \\
\hline $\begin{array}{l}\text { Fifth stage } \\
\text { (1995 onwards }\end{array}$ & $\begin{array}{l}\text { Institutionalisation of } \\
\text { Participatory approach, } \\
\text { Watershed boundary to } \\
\text { political boundary }\end{array}$ & $\begin{array}{l}\text { Gender and social equity consideration, rights and access } \\
\text { to community resources for local communities, indigenous } \\
\text { knowledge integrated into new technology approach. } \\
\text { UGs' formal registration. The link between UG and VDC } \\
\text { became more formal. }\end{array}$ \\
\hline
\end{tabular}

The initiation of people's participation concept for planning and implementation of soil conservation activities started after 1990 in Nepal (Wagley and Bogati, 1999; Wagley and Ojha, 2002). Realizing the fallacy of excluding local people, there was a gradual shift to implement government's soil conservation projects more by Ugs (User groups) based on their own needs. Formation of UGs to run the program was made mandatory.

\section{DISCUSSION}

\section{Strength of the past top-down approach}

In spite of many weaknesses in the past approaches, there are some strong points in management of watersheds and natural resources. The activities were more specific such as terrace improvement and gully control so that results could be seen readily and rapidly. Programs were directly implemented and the costs covered by implementing office. Therefore, there was no financial burden on the local people, as well as less political and local conflicts due to direct implementation by the government.

The major weaknesses of the past approach are listed as follows:

- Focused only on conservation aspects of natural resources.

- Insufficient attention paid to human activities and to needs of people.

- Lack of consideration of economic and environmental impacts.

- Lack of involvement of beneficiaries in planning and implementing interventions.

- Limited scope of projects.

- Lack of long-term commitment to address underlying causes of degradation. 
- Ignored the local knowledge and more emphasis placed on technical aspects rather than local capacity.

- Benefited mostly elite and rural landowners.

Impact of participatory watershed management

The top-down approach during the 70 s and 80 s was focused on degraded land improvement. But, outcomes were very poor because the project designs did not address the local people's needs (Blaikie, 1987; Kumar and Bakshi, 2002). Villagers felt a loss of their grazing land and the planted species were not suitable for fodder (Saxena et al., 2003). For example, conifer species were planted in mountain region of Nepal. The mortality rate was also high, because farmers did not cooperate in plantation and grazed livestock, and burnt vegetation to regenerate new grass. Moreover, the externally introduced seedlings were not suitable for most of local conditions (Saxena et al., 2003).

A study of the Bagmati Integrated Watershed Management Project (BIWMP), covering six districts in mountain region of Nepal showed that it has indeed improved watershed quality and increased productivity and livelihood in its 23 priority sub-watersheds through participatory approach. The project expected $40 \%$ increase in productivity, $25 \%$ more use of currently unproductive land, $40 \%$ female membership in all groups and $80 \%$ decrease in offseason migration. Moreover, $80 \%$ of disadvantage groups (DAGs) and $50 \%$ of women actively participated in the UG activities (BIWMP, 2003).

Similarly, Khadaka and Yadhav (1999) reported a successful example of PWMP at Pipal Tar watershed in Nuwakot. It helped to increase farm income through increased crop productivity and improved degraded land by planting different verities of grasses, fruits and natural regeneration of tree species by controlling open grazing. Community people constructed check dams in various places to stabilize gullies and minimize soil erosion. To review participatory watershed management project, comparison of some direct impacts in the soil conservation activities can be made (Table 4).

Table 4. Comparison of some indicators before and after participatory watershed management program

\begin{tabular}{|c|c|c|c|}
\hline Indicators & Pre project & $\begin{array}{l}\text { At the end of } \\
\text { project }\end{array}$ & References \\
\hline $\begin{array}{l}\text { Runoff (\%) in Fakot watershed, } \\
\text { Dehradun, India }\end{array}$ & 42.0 & 15.0 & (Sastry et al., 2002) \\
\hline $\begin{array}{l}\text { Soil loss (Ton/ha/yr) Fakot } \\
\text { watershed, Dehradun, India }\end{array}$ & 11.1 & 2.7 & (Sastry et al., 2002) \\
\hline $\begin{array}{l}\text { Soil loss (Mg/ha/ yr), (30 \% } \\
\text { reduction) Philippines }\end{array}$ & 65.3 & 45.4 & (Poudel, 2000) \\
\hline $\begin{array}{l}\text { Terrace improvement Yield of } \\
\text { maize (Kg/ ha/ yr) (Bagmati } \\
\text { watershed. Nepal) }\end{array}$ & 1439.0 & 1926.0 & (Pradhan, 2003) \\
\hline $\begin{array}{l}\text { Community Based } \\
\text { Organizations (CBOs) }\end{array}$ & Very few & Many & (MOPE, 2004) \\
\hline
\end{tabular}

An overall analysis of approaches to watershed management reveals that all developing countries in South Asia are incorporating participatory community oriented agendas into national development policies (ESCAP, 1997). The devolution of centralized management of resources and transfer of responsibilities to local communities creates space to accommodate 
local interests, livelihood needs, and empowered resource users to benefit from, as well as influence the outcomes of the policy (Pokharel, 2000; Shackleton et al., 2002). Participatory programs have nurtured a sense of ownership of natural resources to the communities. Ownership inturn helps to increase the people's participation in the development process. It involves self-governance, self-organization and collective mobilization to assert rightful claims to resources from the community and to allocate, distribute, and manage these resources (Sen et al., 1997).

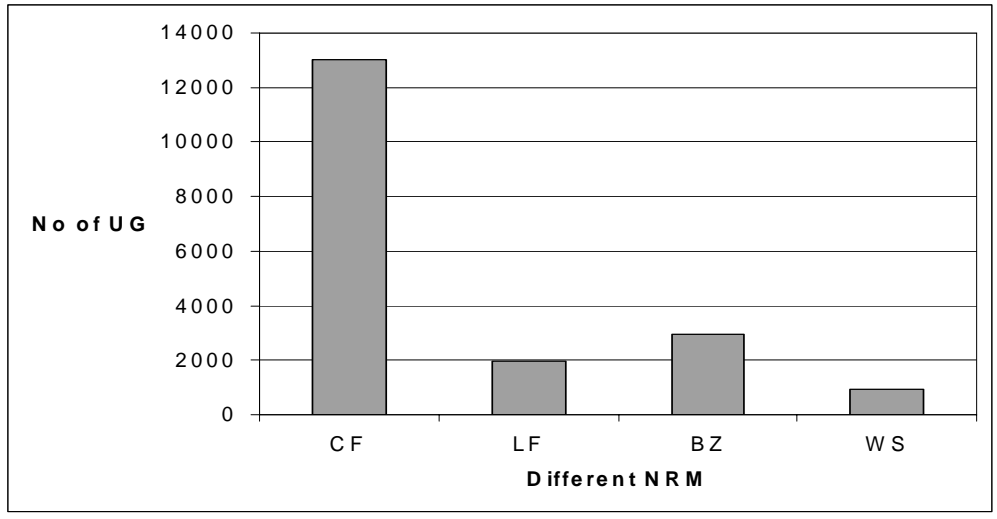

The participatory approach not only improves the management of natural resource but also brings local communities into mainstream of development. Figure 3 shows that more than 16000 CBOs (Community Based Organizations) have been formed at the local level to manage resources in Nepal particularly, in the hills (MOPE, 2004).

Figure 1. Number of UGs in different Natural Resource Management (NRM) program in Nepal, (CF= Community Forestry, LF= Leasehold Forestry, BZ=Bufferzone, WS= Watershed Management (MOPE, 2004).

Community forest (CF) management was a pioneering effort in the area of community based natural resource management (CBNRM). It now has nationwide coverage and strong networking of its FUGs all over the country as a Federation of Community Forest Users Association (Wagley and Ojha, 2002). Moreover, participatory approach is now being applied in other development programs such as irrigation management, farming system, sanitation, small hydropower and related rural development activities.

In summation, the participatory approach to watershed management program can be said to be contributing to the development of five types of capital in rural areas. These are natural capital by improving land, forest condition and water resource management conservation; human capital by empowering the women, poor and disadvantage groups as well as providing skill enhancement training; social capital by forming and mobilizing UGs; financial capital by resource generation, self initiative saving credit program and income generating activities, and physical capital by facilitating different community development works such as trail improvement, water source protection, micro-hydropower generation and school construction.

\section{ISSUES OF PWM IN THE PRESENT CONTEXT}

PWM is effective in soil conservation, community mobilization, and empowering local people for resource management. But, there are some critical issues which are discussed below:

Management issues

Participatory process is a long and costly process. In many developing countries, extension services still suffer from a strong Top-down approach (Michaelsen, 1991; Styczen and Dreyer, 1999). Furthermore, it may be difficult for facilitators and stakeholders in watershed 
management projects to include representatives of all stakeholder groups in management and decision-making processes. In some cases, it may be tempting to exclude some stakeholders from the process because of local power relations and their illegitimacy (Huggins, 2004).

\section{Policy issues}

Participation in conservation programs generally takes place if there exist direct economic benefits (Stocking, 1998). Subsidy policy is not a sustainable option for watershed management programs (Huszar, 1998). Yet in poor mountain communities, where farmers depend for sustenance on crop production in marginal lands, subsidies may be unavoidable to encourage conservation and restoration of degraded lands (Hudson, 1991). In some instances subsidies are misused by local communities by over estimating costs and duplicating the work in the name of participatory approach (Sthapit and Bendtsen, 1999). An example of conflict between local level management in natural resources in Nepal is the government forest policy and local government policy. On one hand, the Forest Act 1993 of Nepal devolves forest management responsibilities to forest users groups as independent organization. On the other hand, the Decentralization Act 1982 gives local governmental units control over all natural resources within their administrative area (Fisher, 2000; Wagley and Ojha, 2002). Food price policy and subsidies may favour cultivation of certain crops and also exploitation of marginal lands (Michaelsen, 1991), which leads to further degradation. Similarly, insecure land tenure may make farmers more interested in occupying land than in sustaining its long-term production capacity. The appropriate property right system can provide tenure security while at the same time, accommodating the interests of multiple uses (Swallow et al., 2001).

\section{Poverty issues}

Poverty has a tendency to exacerbate the participatory process. For example, in the hills of Nepal, poor users generally have lower accessibility to fodder and fuelwood and thus added burden of forest management and lack of purchasing power for forest resources. Moreover, the poor sectors of society tend to have less participation in forest management decisions due to several constraints like lack of time, seasonal migration, low level of education and awareness and lack of confidence. Also, groups that depend heavily on daily wage labour or seasonal migration find it difficult to contribute their share of the cost of protection (Conroy et al., 2002). Furthermore, some UGs have built schools, without providing the support to enable children of poorer households to attend school (Malla, 2001). Similarly, watershed development projects are essentially land based development activities that aid in raising the productivity of the farmers. However, being incidental to the treatment program, this chiefly helps the large farm size farmers who are centrally positioned and are able to manipulate project management in order to obtain maximum benefits (Farrington and Baumann, 2003).

\section{Upland-lowland issues}

Sound natural resource management in the uplands also often provides environmental services for low lands and beyond (Swallow et al., 2001). The protection of forests in upland areas, for instance, reduces soil erosion, sedimentation, and flooding downstream (Pandey, 2003). However, as hardships persist in upland areas due to lack of land tenure and access to markets and negative impacts of national development processes, communities are often unable to tap the full benefits of sustainable natural resource management (Swallow et al., 2001). As upland communities rarely receive the benefits of the environmental services they provide, there is a critical need to understand how environmental service transfer payments 
can best be implemented to improve the livelihoods of upland communities in Nepal (Malla, 2001; Pandey, 2003).

\section{Institutional issues}

Most of the watershed related activities in Nepal have been designed with an assumption that willing participation of the local community will be channeled to meet the goals and objectives of watershed rehabilitation. However, there is a big gap between expectations of the people and the institutional arrangements to meet these expectations. Sheng (1999) points out the problems of coordination in many watershed programs in developing countries. Each agency has its own separate plans and responsibilities (Paudel, 2002). Moreover, watershed boundaries and political boundaries do not coincide which tends to aggravate participatory management. Currently, the PWM program has considered the political as well as social boundaries rather than hydrological. The activities are carried out according to community territories (settlements) and administrative divisions (Village Development committee and Ward) often including areas outside the hydrological watershed. Some other conflicting issues regarding equity, poverty, co-ordination, revenue sharing, community forestry taxation and highland-lowland and indigenous user rights exist in participatory natural resource management program in Nepal (Winrock, 2002). These issues should be addressed to plan and implement the watershed management programs for sustainable mountain development.

\section{CONCLUSION}

PWM is a focal program in many developing countries at present. Increasing population creates more pressure on natural resources in South Asian countries particularly mountain regions resulting in the deterioration of watersheds. To overcome the watershed degradation problems many developing countries have practiced different watershed management approaches from top-down and sectoral to bottom-up, participatory and integrated types. Both, top-down and bottom-up, approaches have strengths and weaknesses in implementation of programs. However, the past top-down approach has many limitations for sustainable watershed management, because it ignored needs of local people. Since last decade participatory watershed management approach has became popular in developing countries. Participation of local people in planning, implementing, decision making and monitoring are being institutionalised in GO/ NGO based watershed management programs. This approach is a win-win solution for the government, the people and the environment.

Nepal is a leading country in community based natural resources management in South Asia Region. Peoples' participation is mandatory in government policy in all natural resource management programs. The participatory approach has empowered local people to take active decisions and responsibilities at the local level in natural resource management. It has helped to bring large rural communities into the mainstream of development. Furthermore, it brought active women's participation in community development and empowered them to exercise their rights and responsibilities. Initiation and implementation of the forest policy and programs adopting the principle of community-based decentralization has changed the scenario of the natural resource management and community mobilization in the rural areas. Apparently, there is an urgent need to address the livelihoods of the upland poor communities and coordination among the national and local organizations and multiple users of watershed resources. The present policies and programs are directed towards poor communities and empowering rural marginalized groups including women. Clearly, local people are the primary 
managers of the natural resources, and they should be encouraged to take responsibility in a participatory, integrated and sustainable manner.

\section{REFERENCE}

Adams, W. M., 2001. Green Development: Environment and Sustainability in the Third World. London: Routledge.

Archer, S. and F. E. Smeins, 1991. Ecosystem-level Processes: Grazing Management, an Ecological Perspective. Portland: Timber Press pp109-130.

Balogun, M. J., 2000. The Scope for Popular Participation in Decentralization, Community Governance, and Development: Towards a New Paradigm of Centre Periphery Relations. RegionalDevelopment Dialogue 21(1), 21-39.

BIWMP, 2003. An Overview of the Bagmati Integrated Watershed Management Project (BIWMP). Kathmandu, Nepal: Bagmati Integrated Watershed Management Project, Department of Soil Conservation and Watershed Management.

Blackburn, J. and J. Holland(eds. ), 1998. Who Changes? Institutionalising Participation in development. London: Intermediate Technology Publication Ltd.

Blaikie, P., 1987. Explanation and Policy in Land Degradation and Rehabilitation for Developing Countries. Land Degradation and Rehabilitation, 1, 23-27.

Blaikie, P., 2001. Is Policy Reform Pure Nostaligia ? A Himalayan Illustration: Barkeley Workshop on Environmental Politics. California, Berkeley: Institute of International Studies, University of California.

Blair, H., 2000. Participation and Accountability in the Periphery: Democratic Local Governance in Six Countries. World Development 28, 21-39.

Botero, L. S., 1986. Incentives for Community Involvement in Upland Conservation. Strategies, approaches and system in integrated watershed management. Rome: FAO Conservation Guide 14.

Brooks, N. K., P. F. Folliot and J. L. Thames, 1991. Watershed Management: A Global Perspective, Hydrology and the Management of Watersheds. Ames, lowa: lowa State University Press pp1-7.

Brown, S. and G. Kennedy, 2005. A case study of Cash Cropping in Nepal:Poverty Alleviation or Inequity ? Agriculture and Human Values, 22:105-116.

Carson, B., 1992. The land, The farmer, and The future: A Soil Fertility Management Strategy for Nepal. Kathmandu: ICIMOD

CIESIN, 2004. The Trustees of Columbia University in the City of New York: Columbia Earth Institute.

Cohen, J. and N. Uphoff, 1977. Rural Development Participation: Concept and Measures for Project Design, Implementation and Evaluation: Cornell University, Ithaca.

Conroy, C., A. Mishra, and A. Rai, 2002. Learning from Self Initiated Community Forest Management in Orissa India. Forest Policy and Economics, 4, 227-237.

Corn, M. L., 1993. Ecosystems, Biomass, and Watersheds: Definitions and Use. Washington, DC.: National Council for Science and the Environment.

Datta, S. K. and K. J. Virgo, 1998. Towards Sustainable Watershed Development through People's Participation: Lesson from the Lesser Himalaya, Utter Pradesh, India. Mountain Research and Development 18(1), 213-233.

Douglass, M. and P. Lawrence, 1997. Planning Soil Conservation Project through Participation. A guide Report, ODI, 139. UK: Department for International Development, HR, Wallingford Group Limited. pp10-11.

DSCWM, 2004. Soil conservation and watershed management measures and low cost techniques. Kathmandu, Nepal: Soil Conservation and Watershed Management Component (NARMSAP)/ Department of Soil conservation and Watershed Management (DSCWM). pp1-2.

Eckholm, E. 1975. The Deterioration of Mountain Environments. Science, 189, 764-770.

ESC, 2001. Agriculture, Land and Desertification: Report of the Secretary General. Economic and Social Council: United Nations.

ESCAP, 2003. Rural Development and Poverty in South Asia: Development papers No. 23 United Nation http:// www. unescap.org/ pdd/ publications/dp23/ DP_23. pdf. 
ESCAP, 1997. Guidelines and Manual on Land-Use Planning and Practices in Watershed Management and Disaster Reduction. Bangkok: Economic and Social Commission for Asia and the Pacific, United Nation.

FAO, 1982. Participation in Forestry. Wageningen, Netherlands: Department of Forest Management, Agriculture University.

Farrington, J. and P. Baumann, 2003. Decentralising Natural Resource Management: Lesson from Local Government Reform in India. London: Natural Resource Perspectives 86: Overseas Development Institute.

Farrington, J. and C. Lobo, 1997. Scaling-up Participatory Watershed Development in India: Lessons from the Indo- German Watershed Development Program. London: Overseas Development Institute, pp1-5.

Fisher, R. J . (ed. ), 2000. Decentralization and Devolution in Forest Management: A Conceptual Overview. Bangkok, Thailand: RECOFCT/FAO.

Gill, G. J., 1995. Major Natural Resource Management Concerns in South Asia: International Food Policy Research Institute.

GHF, 2006. The World Fact Book: Population Growth rate estimate.: Global Health Facts.

Hudson, N. W., 1991. A Study of the Reasons for Success or Failure of Soil Conservation Projects. Rome. : FAO soil bulletin, 64.

Huggins, C., 2004. Managing Watersheds, Managing Conflict, 4th. Regional Session of the Globel Biodiversity Forum for Africa. Dar-E -Salaam, Tanzania: Global Biodiversity Forum for Africa.

Hurni, H. and K. Tato, (eds.), 1992. Soil Conservation for Survival: Soil and Water Conservation Society, USA.

Huszar, P. C., 1998. Including Economics in the Sustainable Equation: Upland Soil Conservation in Indonesia. In: H. P. Blume, H. Eger, E. Fleischhauer, A. Hebel, C. Reij and G. K. Steiner (eds.), Towards sustainable land management:Advances in Geoecology. NewDelhi: pp889-96.

Ives, J. D., 2004. Himalayan Perceptions. London and New York: Routledge.

Ives, J. D. and B. Messerli, 1989. The Himalayan Dilemma: Reconciling Development and Conservation. , . London: Routledge, pp1-10.

JICA/ HMG(N), 1998. The Development Study on Integrated Watershed Management in the Western Hills of Nepal. Final Report. Kokusia, Kogyo Co. Ltd: Japan Forest Technical Association.

J odha, N. S., 1995. The Nepal Middle Mountains. In: J. Kasperson, R. E. Kasperson and B. L. Turner (eds.), Regions at risk: comparisons of threatened environments (pp. 140-185). Tokyo: United Nations University Press.

J ohnson, N. L., H. M. Ravnborg, O. Westermann and K. Probst, 2001. User Participation in Watershed Management and Research. Water Policy, 3:507-520.

Kerr, J. M., N. K. Sanghi and G. Sriramappa, 1996. Subsidies in Watershed Development Projects in India: Distortions and Opportunities. Gatekeeper series No.61. London: IIED

Khadaka, B. and R. P. Yadhav, 1999. People's Participation in Rehabilitation of a Degraded Watershed A case study of Sukauri Khola Micro watershed. Paper presented at the Danida's Third International Workshop on watershed Development, Kathmandu, Nepal, pp309-317.

Kumar, N. and S. Bakshi, 2002. Making and Breaking a Community Forestry Institution: A Case Study. Forest, Trees and Livelihood, 12:165-174.

Kumar, S., 2002. Method for Community Participation. London, UK: WCIB 4HL, pp20-45.

Lal, R., 1998. Soil Erosion Impact on Agronomic Productivity and Environment Quality. Critical Reviews in Plant Sciences, 17(4); 319-464.

Lal, R., 2002. Soil Carbon Sequestration in China through Agricultural Intensification, and Reforestation of Degraded and Desertified Ecosystems. Land Degradation and Development, 13:469-478.

Leganza, G. and A. Brown, 2004. Top-down versus Bottom-up: Approaches to Enterprise Arctitecture: Helping Business Thrive on Technology Change. Forester Research, Inc. http:// www. forrester.com/go

Maarleveld, M., 1998. Improving participation and cooperation at the local level: lesson from economics and psychology towards sustainable land use. In: H. P. Blume, H. Fleischhauer, E. Eger, A. Hebel, C. Reij and G. Steiner (eds.), Advance in Geology. New Delhi, India, pp971-977. 
Makela, M., 1999. Community Based Environmental Protection and Natural Resources Management. Helsinki: Ministry of Foreign Affairs of Finland, Department for International Development Cooperation, pp1-10.

Malla, Y. B., 2001. Impact of Community Forestry Policy in Rural Livelihoods and Food Security in Nepal. Unasylva Watershed Management, 200:38-45.

Meadows, E., 2003. Soil Erosion in the Swartland, Western Cape Province, South Africa: Implications of Past and Present Policy and Practice. Environmental Science and Policy 6:17-28.

Michaelsen, T., 1991. Participatory Approach in Watershed Management Planning. Unasylva Watershed Management 42(164):1-15.

Montgomery, D. R., G. Grant and E. K. Sullivan, 1995. Watershed Analysis as a Framework for Implementing Ecosystem Management. Water resource bulletin, pp369-386.

MOPE, 2004. Nepal- National Action Program on Land Degradation and Desertification: Ministry of Population and Environment, Kathmandu Nepal.

Mountain, 2002. Watershed Management. Beyond the International Year of Mountains. Retrieved December12, 2004, http:// www. mountainpartnership. org/themes/ i-watershed. html

Narwal, R. P., B. R . Singh and R. S. Antil(eds.), 2003. Soil Degradation as a Threat to Food Security. Washington, D. C.: Lewis Publishers, pp97.

Ohler, F. M. J., B. K. Rimal and P. Warren(eds.), 2000. Participatory and Integrated Watershed Management in Nepal. A Resource Book for District Soil Conservation Officers. Kathmandu: FAO, GCP, INT/ 542/ ITA. pp25-28.

Oldeman, L. R., 1994. The Global Extent of Soil Degradation. In: D. J. Greenland and I. Szabolces (eds. ), Soil Resiliencies and Sustainable Land Use (pp. 99- 18). Walling, UK: CAB International.

Ozyuvaci, N., S. Ozhan and E. Görcelioðlu, 1997. Integrated Watershed Management for Sustainable Development of Renewable Natural Resources. Paper presented at the XI WORLD FORESTRY CONGRESS, Antalya, Turkey.

Pandey, B., 2003. Promoting Sustainable Livelihoods in the Kulekhani Watershed. Project report. Kathmandu, Nepal: Winrock International.

Partap, T. and H. R. Watson, 1994. Sloping Agricultural Land Technology (SALT): A Regenerative Option for Sustainable Mountain: FarmingOccasional Paper, No.23. Kathmandu, Nepal: ICMOD.

Paudel, G. S., 2002. Research Issues on Watershed Management in Developing Countries. Rural Development, 21:187-214.

Paudel, G. S. and G. B. Thapa, 2004. Impact of social, institutional and ecological factors on land management practices in mountain watershed of Nepal. Applied Geography, 24:35-55.

Pender, J. and S. Ehui, 2000. Policies for Sustainable Land Management in the Highlands of Ethiopia. Washington, D. C: International Food Policy Research Institute (IFPRI).

Peraz, C. and H. Tschinkel, 2003. Improving Watershed Management in Developing Countries: A Framework for Prioritizing Sites and Practices. U.K: Agriculture Research and Extension Network.

Perera, N. and K. Fernado, 2004. Sustainable Land Management: South Asia Perspectives. Colombo, Sri Lanka.: South Asia Cooperative Environment Program,.

Pokharel, B., 2000. Contribution of Community Forestry to People's Livelihoods and Forest Sustainability: Experience from Nepal: http:// www.wrm. org. uy/ countries/ Asia/ Nepal.html

Poudel, D. D., 2000. Farmer Participatory Research to Minimize Soil Erosion on Steepland Vegetable Systems in the Philippines. Agriculture Ecosystems and Environment 79:113-127.

Pradhan, B. B., 2003. Watershed Management in Terrace Farming. Kathmandu, Nepal: Institute for Sustainable Development.

Pretty, J., 1995. A Trainer's Guide for Participatory Learning and Action. IIED Participatory Methodology series. London: IIED.

Pretty, J. and P. Shah, 2000. Soil and Water Conservation: A Brief History of Coercion and Control. In: F. Hinchcliffe, J. Thompson, J. N. Pretty, I. Guijt and P. Shah (eds.), Fertile ground: The impact of participatory watershed management. London: Intermediate Technology Publications, pp1-12.

Rasul, G. and M. Karki, 2007. A Pro-poor Policy Agenda for Sustainable Agricultural Development in the Hindu Kush Himalyan Region. Kathmandu, Nepal: International Centre for Integrated Mountain Development (ICIMOD), 
Rhoades, R. E., 1998. Participatory Watershed Research and Management: Where the Shadows Fall.Gatekeepers Series, no 81. London: International Institute for Environment and Development (IIED).

Sastry, G., O. Prakash, Y. R. Reddy and H. P. Singh, 2002. Watershed Management Program for Increasing Land Productivity and Appropriate Withdrawal Strategies for Long Term Sustainability in Rainfed Lands of India, 12th. International Soil Conservation conference. Beijing, China, pp473-76.

Saxena, K. G., K. S. Rao, , K. K. Sen, R. K. Maikhuri and R. L. Semwal, 2003. Integrated Natural Resource Management: Approaches and Lessons from the Himalaya. In: B. M. Campbell and J. A. Sayer (eds.), Integrated Natural Resource Management (pp. 211-225): CAB International Centre for International Forestry Research.

Scheer, S. J. 1999. Soil Degradation: A Threat to Developing Country Food Security in 2020? Food, Agriculture and the Environment. Discussion Paper. Washington, D.C.: International Food Policy Research Institute.

Sen, K. K., R. L. Semwal, U. Rana, S. Nautiyal, R. K. Maikhuri and K. S. Rao, 2002. Patterns and Implications for Land Use/ Cover Change: A Case Study in Pranmati Watershed (Garhwal Himalaya, India). Mountain Research and Development, 22:56-62.

Sen, S. K., T. Partap and P. N. Sharma, 1997. Farmer-Led Trainers' Resource Book: Participatory Watershed Management Training in Asia Program. Kathmandu, Nepal: Netherlands/ UNDP/ FAO, GCP/ RAS/ 161/ Net-RAS/ 93/ 062, pp11.

Shackleton, S., B. M. Campbell, E. Wollenberg and D. Edmunds, 2002. Devolution and Communitybased Natural Resource Management: Creating Space for Local People to Participate and Benefit. London: Natural Resource Perspectives, ODI. No. 76.

Shah, P. B. and H. Schreier, 1995. Maintaining Soil Fertility in Agriculture and Forestry. Paper presented at the Challenges in Mountain Resources Management in Nepal Process Trend and Dynamics in Middle Mountain Watersheds, Kathmandu, Nepal, pp171-182

Sharma, P. N. and M. P. Wagley, 1996. Case Studies of People's Participation in Watershed Manageent in Asia. Kathmandu, Nepal: UNDP/ FAO/ Netherlands, RAS, pp47-50

Sheng, T. C., 1999. Important and Controversial Watershed Management Issues in Developing Countries. Paper presented at the 10th. International Soil Conservation Organization Meeting, Purdue University, USA.

Sikka, A. K. and J. S. Samra, 2000. Participatory Watershed Management: A New Paradigm for Integrated Watershed Management. Paper presented at the International Conference on Integrated Water Resource Management for Sustainable development, Roorkee, India, pp900-910.

Sitaula, B. K., P. L. Sankhayan, R. M. Bajrachrya and B. R. Singh, 2004. Analysis of Forest Degradation, Soil Erosion and Carbon Losses in a Mid-Hill Watershed of Nepal: A Bio- Economic Modelling Approach. Special Issue on Land and Forest Degradation. Forestry, J ournal of Institute of Forestry, Pokhara, 12:45-48.

Sthapit, K. M. and K. S. Bendtsen, 1999. Pitfalls in Participatory Watershed Management: A Case Study from Nepal. Paper presented at the Danida's Third International Workshop on Watershed Development, Kathmandu.

Stocking, M., 1998. Conditions Enhanced Cooperation Between People and Institutions. In: H. P. Blume, H. Eger, E. Fleischhaurer, A. Hebel, C. Reiji and K. G. Steiner (eds.), Towards Sustainable Land Use: Advance in GeoEcology. Reiskrchen, India: CATENA VERLAG, pp857-865.

Styczen, M. and S. Dreyer, 1999. Are We Finally Doing it Right? A Review of Problems and Strategies in Soil and Water Conservation. Paper presented at the Danida's Third International Workshop on Watershed Development, Kathmandu.

Swallow, M. B., N. L. Johnson and R. S. Meinzen-Dick, 2001. Working with People for Watershed Management. Water Policy, 3:449-455.

Thurow, T. and A. J uo, 1995. The Rationale for Using a Watershed as a Basis for Planning and Development. In Agriculture and Environment; Bridging Food Production and Environmental Protection in Developing Countries. American Society of Agronomy Special Publication, 93-116.

Townsely, P., 1996. Rapid Rural Appraisals and Participatory Rural Appraisal and Aquaculture. Rome: FAO.

Turton, C., 2000. Sustainable Livelihoods and Project Design in India. London, SW1E 5DP UK: Overseas Development Institute 
UNCED, 1992. Agenda 21. Rome, Italy: United Nations Commission on Environment and Development. UNEP, 2004. Planning and Management of Lake and Reservoirs: An Integrated Approach to Eutrophification: United Nations Environment Program, Division of Technology and Economics.

Wagley, M. and P. R. Bogati, 1999. State of the Art and Status of Watershed Management in Nepal. Paper presented at the Danida's Third International Workshop on watershed Development, Kathmandu, pp5-14.

Wagley, M. P. and H. Ojha, 2002. Analyzing Participatory Trend in Nepals' Community Forestry. Policy trend report. Forest and Livelihood, pp122-142.

Walker, B. and S. Carpenter, 2002. Resilience Management in Social Ecological System: A Working Hypothesis for a Participatory Approach. Conservation Ecology 6(1).

WFP, 2002. Natural Resource Management and Livelihoods. Programming Guidance: World Food Program.

Winrock, 2002. Emerging Issues in Community Forestry in Nepal. Kathmandu, Nepal: Occasional Papers Series No. 3, Winrock.

WRI, 2003. Decentralization: A Local Voice, Decision for the Earth: Balance, Voice, and Power: World Resource Institute UNDP, UNEP, World Bank.

WRI, 1985. Tropical forests: A call to action', Report of an international task force convened by the World Resource Institute(WRI). Washington DC: World Bank and the United Nations Development Program.

Young, A., 1994. Land Degradation in South Asia: Its Severity, Causes, and Effects upon the People. . Rome: FAO. 